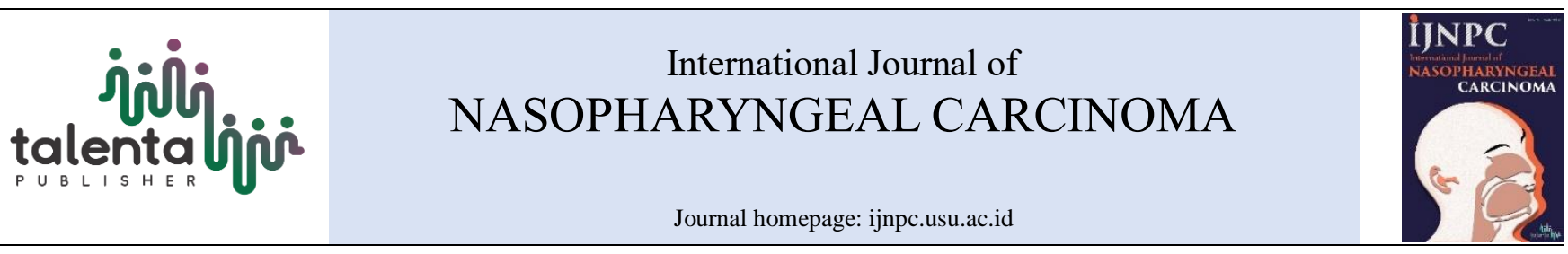

\title{
CORRELATION BETWEEN S100 PROTEIN EXPRESSION WITH CLINICAL STAGING NASOPHARYNGEAL CARCINOMA TYPE III
}

\author{
Ismi Cahyadi ${ }^{*}$, Yussy Afriani Dewi², Nur Akbar Aroeman ${ }^{2}$ \\ ${ }^{I}$ Department of Otolaryngology Head and Neck Surgery, Faculty of Medicine Swadaya Gunung Jati University/Waled Regional Hospital \\ ${ }^{2}$ Department of Otolaryngology Head and Neck Surgery, Faculty of Medicine Padjadjaran University/Hasan Sadikin General Hospital
}

\begin{abstract}
Introduction: Nasopharyngeal carcinoma is the most found head and neck cancer, which originated from a nasopharyngeal epithelial cell, and predilection site commonly at rosen muller fossa. S100 protein inflammatory mediators are involved in the regulation of cellular processes including inflammation and malignancy. S100 protein plays a central role in the proliferation, regulation of cell apoptosis and metastasis causing continuing growth of cancer cells through activation of STAT3 by IL-6, NF- $\kappa \mathrm{B}$, ROS.

Objective: This study aimed to determine the correlation between $\mathrm{S} 100$ protein expression levels to the clinical stage of NPC WHO type III.

Method: This research is a cross-sectional analytic study. This study was held in the Anatomical Pathology Department of Hasan Sadikin Hospital from August until October 2015. The study was conducted using 29 pieces of secondary data, medical records and paraffin blocks anatomical pathology of NPC patients were examined S100 protein immunohistochemistry.

Result: This study was performed from 29 subjects (18 males and 9 females). There was a strong positive correlation between histoscore $\mathrm{S} 100$ protein expression with clinical staging $\mathrm{p}<0.05$. There is a significant correlation between S100 protein expression with the clinical stage of NPC WHO type III using double regression analysis $(\mathrm{F}=15.676, \mathrm{p}=0.000)$.

Conclusion: There were significant correlation S100 protein expression levels to clinical stage nasopharyngeal carcinoma WHO type III.
\end{abstract}

\section{Article Info}

Keywords:

Nasopharyngeal carcinoma, S100 protein, clinical staging

\section{*Corresponding author:}

Address: Jl. Prabu Kiansantang No.4, Waled Kota, Waled, Cirebon, Jawa Barat 45187

e-mail: ismicahyadi83@gmail.com

\section{INTRODUCTION}

Nasopharyngeal carcinoma (NPC) is the most found malignant tumor in the head and neck area originating from nasopharyngeal epithelial cells [1]. The highest incidence of NPC was found in Guangdong Province of South China with a frequency of 100 times more than the Caucasians which is 17.8 per 100,000 population per year. In Indonesia, NPC is in the fourth place of all malignancies and is ranked first in the field of Ear Nose Throat Health Head and Neck Surgery. The incidence of NPC in Indonesia is 6.7 per 100,000 populations per year with the highest age incidence of 4-5 decades, the ratio between men and women is 2-3: 1 . The prevalence of NPC in the Department Otorhinolaryngology Head and Neck Surgery Dr. Hasan Sadikin Bandung during the period of 2010-2014 was 39.4\% [2-5]. Nasopharyngeal carcinoma is still difficult to diagnose because the hidden nasopharyngeal location and initial clinical symptoms are not typical. Most NPC patients come with complaints of advanced neck lymph nodes so that the prognosis becomes worse [1-6].

The S100 protein is an inflammatory mediator released due to infection or inflammation as a danger signal. The high level of S100 protein is a sign of repeated infection and inflammatory reactions that can be found in tumor epithelium. Tsuji's research in 2006 stated that lymphocyte infiltration in NPC would cause an increase in S100 protein which is characterized by the distribution of Langerhans cells and reticulum [7, 8]. The infected nasopharyngeal epithelium VEB provides an increased response to interleukin- 6 that involves the signal transducer activation activator of transcription 3 to promote growth and invasive factors [9]. The response is mediated by granulocyte activity involved in the process of NPC by inflammation. S100 protein is a protein found in granulocytes and macrophages. In the inflammatory process, reactive oxygen species are formed. Increased ROS levels will cause activation of transcription factors such as NF- $\kappa$ B. Nuclear Factor-Kappa B has a role in cell immortality. An increase in NF- $\mathrm{KB}$ is followed by an increase in IL-6 and S100 protein indicating a malignancy process. Besides, that ROS will also damage DNA so that it promotes cell proliferation or suppresses apoptosis [10-13]. This process results in loose bonds. Some S100 proteins are affected by the process, so they are used as specific target proteins.

In the metastatic process of NPC, $\mathrm{S} 100$ protein is a mediator of $\mathrm{p} 53$ as a tumor suppressor gene. In NPC, high levels of p53 were found according to their stage so that they could predict an increase in expression of S100 protein found in tumor tissue and neck KGB of NFF18 patients. In a study in 2012, by Maletzki, expression of S100 protein was obtained from the presence of langerhans cells in carcinoma. Langerhans cells can be detected not only in the epidermis but also in the esophageal, tonsillar, nasopharyngeal, and lymphoid tissue epithelium. In NPC there is an increase in the number of Langerhans cells according to the tumor infiltration $[7,8,10,14]$.

From a immunohistochemical examination of $\mathrm{S} 100$ protein, we can identify Langerhans cells in both mature and immature forms. The picture of Langerhans cells at various stages in NPC shows tumor infiltration according to their progression. Progressivity was assessed based on the clinical stage, and the degree of expression of S100 protein that appeared by Langerhans cells from immunohistochemical examination [7, 8, 10, 14]. S100 protein examination by immunohistochemistry has advantages over other examinations, which are easier, not invasive, and cheaper.

\section{MATERIAL AND METHODS}

This research is a cross-sectional analytic study and was held in Anatomical Pathology Department of Hasan Sadikin Hospital from August until October 2015. The study was conducted using 29 pieces of secondary data, medical records and paraffin blocks anatomical pathology of NPC patients were examined S100 protein immunohistochemistry. 


\section{RESULT}

The results of examination of S100 protein expression in WHO type III NPC patients who performed immunohistochemistry based on table 1, the distribution of $51-80 \%$ as many as 2 people $(6.9 \%)$, and 27 people $(93.1 \%)$ in distribution $>80 \%$. In the assessment based on intensity, there was a weak intensity of 5 people (17.2\%). Moderate intensity was found in 8 people $(27.6 \%)$, and a strong intensity of 16 people $(55.2 \%)$.

Table 1. Results for Examination of S100 Protein Expressions in WHO type III NPC patients

\begin{tabular}{lcr}
\hline Expressions & Results & $\%$ \\
\hline Distribution & 2 & 6.9 \\
$50-80 \%$ & 27 & 93.1 \\
$80 \%$ & & 17.2 \\
Intensity & 5 & 27.6 \\
$\quad$ Weak & 8 & 55.2 \\
$\quad$ moderates & 16 & \\
$\quad$ strong & & \\
Hystoscor & & \\
$\quad$ Mean : 9.2 (3.07) & & \\
$\quad$ Median: 9 & & \\
$\quad$ range: $4-12$ & &
\end{tabular}

Table 2. Distribution of S100 proteins according to WHO type III NPC stages

\begin{tabular}{lrrrrcr}
\hline \multirow{2}{*}{ Distribution } & \multicolumn{9}{c}{ Stadium } & \multirow{2}{*}{ Results } & \multirow{2}{*}{ P } \\
\cline { 2 - 5 } & I & II & III & IV & & \\
\hline$<20 \%$ & 0 & 0 & 0 & 0 & 0 & \multirow{2}{*}{0.791} \\
$20-50 \%$ & 0 & 0 & 0 & 0 & 0 & \\
$51-80 \%$ & 0 & 0 & 2 & 0 & 2 & \\
$>80 \%$ & 2 & 6 & 8 & 11 & 27 & \\
\hline
\end{tabular}

Spearman test $\mathrm{P}<0.005$

Table 2 shows the amount of S100 protein distribution according to the stage. From the data obtained in stage I there were 2 subjects with S100 protein distribution $>80 \%$. In stage II there were 6 subjects with S100 protein distribution $>80 \%$. Stage III there are 2 subjects with a distribution of $51-80 \%$ and 8 subjects distributed $>80 \%$, and at stage IV distribution of S100 protein $>80 \%$. With the Spearman statistical test, the value of $p=0.791$ showed that there was no relationship between the distribution of S100 protein and the clinical stage.

Table 3. S100 protein intensity in WHO type III NPC patients

\begin{tabular}{lllllll}
\hline \multirow{2}{*}{ Intensity } & \multicolumn{9}{c}{ Stadium } & Results & \multirow{2}{*}{ P } \\
\cline { 2 - 5 } & I & II & III & IV & & \\
\hline Weaks & 2 & 3 & 0 & 0 & 5 & \multirow{2}{*}{0.000} \\
Moderates & 0 & 2 & 4 & 2 & 8 & \\
Strong & 0 & 1 & 6 & 9 & 16 & \\
\hline
\end{tabular}

Spearman test $\mathrm{P}<0.05$

Table 3 shows the S100 protein intensity according to the stage. In stage I there were 2 subjects with weak intensity. Stage II there are 3 subjects with weak intensity, 2 subjects of moderate intensity, and 1 subject with strong intensity. Stage III there are 4 subjects with moderate intensity and 6 subjects with strong intensity. In stage IV there are 2 subjects with moderate intensity and 9 subjects with strong intensity. With the Spearman statistical test, the intensity ratio based on the clinical stage obtained with a value of $\mathrm{p}=0.000$, there is a significant relationship between the comparison of $\mathrm{S} 100$ protein intensity to the clinical stage.

Table 4. Histoscore results

\begin{tabular}{lcrrrrr}
\hline \multirow{2}{*}{ Histoscore } & \multicolumn{9}{c}{ Stadium } & Results & \multirow{2}{*}{ P } \\
\cline { 2 - 5 } & I & II & III & IV & & \\
\hline Negatif & 0 & 0 & 0 & 0 & 0 & \multirow{2}{*}{0.000} \\
Weak & 0 & 0 & 0 & 0 & 0 & \\
Moderate & 2 & 3 & 0 & 0 & 5 & \\
Strong & 0 & 3 & 10 & 11 & 24 & \\
\hline
\end{tabular}

Spearman test $\mathrm{P}<0.05$

Table 4 shows histoscore results in WHO type III NPC patients. From the data obtained in stage I histories with moderate positive as many as 2 subjects. In stage II, moderately positive and strong positive histories were obtained for each of the 3 study subjects. In stage III there were 10 positive positive histories in the study subjects. With the Spearman statistical test obtained a comparison of the $\mathrm{S} 100$ protein histories based on the clinical stage with a value of $\mathrm{p}=0.000$, there is a significant relationship between the comparison of S100 protein histories to the clinical stage.
Table 5. The relationship between age, sex, and expression of S100 protein with clinical stage

\begin{tabular}{lccccc}
\hline \multicolumn{1}{c}{ Variabel } & Koefisien B & SE $(\mathbf{B})$ & Value t & Value P & $\begin{array}{c}\text { Anova } \\
\text { test }\end{array}$ \\
\hline Age & -.019 & 0.009 & -2.086 & 0.047 & - \\
Sex & 0.438 & 0.226 & 1.939 & 0.064 & F: 15.676 \\
Protein S100 & 0.190 & 0.040 & 4.724 & 0.000 & p: 0.000 \\
konstanta & 1.489 & 0.723 & 2.060 & - & - \\
\hline
\end{tabular}

$\mathrm{r}^{2}(\%)=65.3 \% ; \mathrm{SE}:$ Standard Error

Table 5 explains the relationship between age, sex, and expression of S100 protein with a clinical stage based on multiple regression analysis, with the results of the B coefficient $\mathrm{S} 100$ protein expression= 0.190 , with a value of $\mathrm{t}=4.724$ and $\mathrm{p}=0.000$. With the ANOVA test, get the Fischer statistical value $=15.676$ and a significant value of 0.000

\section{DISCUSSION}

From the data of S100 protein expression, it was found that the distribution of $50-80 \%$ amounted to $6.9 \%$ and $>80 \%$ as much as $93.1 \%$. The amount of S100 protein distribution according to the stage, from the data obtained in stage I there were 2 subjects with $\mathrm{S} 100$ protein distribution $>80 \%$. In stage II there were 6 subjects with $\mathrm{S} 100$ protein distribution $>80 \%$. Stage III there are 2 subjects with a distribution of $51-80 \%$ and 8 subjects distributed $>80 \%$, and at stage IV distribution of S100 protein $>80 \%$. With the Spearman statistical test, the value of $p=0.791$ showed that there was no relationship between the distribution of $\mathrm{S} 100$ protein and the clinical stage.

On examination of the $\mathrm{S} 100$ protein intensity, we found a weak intensity of $17.2 \%$, moderate $27.6 \%$ and strong $55.2 \%$. Based on the stage of the number of subjects S100 protein intensity in stage I, there were 2 subjects with weak intensity. Stage II there are 3 subjects with weak intensity, 2 subjects of moderate intensity, and 1 subject with strong intensity. Stage III there are 4 subjects with moderate intensity and 6 subjects with strong intensity. In stage IV there are 2 subjects with moderate intensity and 9 subjects with strong intensity. With the Spearman statistical test, the intensity ratio based on the clinical stage obtained with a value of $p=0.000$, there is a significant relationship between the comparison of $\mathrm{S} 100$ protein intensity to the clinical stage.

Histoscore results were based on stages of WHO type III NPC patients, from data obtained in stage I histories with moderate positive as many as 2 subjects. In stage II, moderately positive and strong positive histories were obtained for each of the 3 study subjects. In stage III there were 10 positive histories in the study subjects. In stage IV the positive histories were 11 subjects, with a value of $\mathrm{p}<0.005$ with a mean of 9.2 , median 9 , and a range of 4-12. This shows a strong positive imunoexpressive result.

The relationship between the expression level of S100 protein and clinical stage based on multiple regression analysis showed that the expression of $\mathrm{S} 100$ protein with a coefficient $\mathrm{B}=0.190, \mathrm{t}=4.724$ and $\mathrm{p}<0.005$. The regression equation is clinical stage $=1,489$. $0.019 *$ age $+0.438 * \mathrm{sex}+0.190 *$ protein $\mathrm{S} 100(\mathrm{r} 2 \%=63.3 \%)$. In the Anova statistical test, the Fischer value of 15,676 and sig was obtained. The p-value 0.000 in the regression model means that this multiple regression analysis models are significant. In this study, it was found that there was a correlation between the levels of expression of $\mathrm{S} 100$ protein towards the clinical stage of WHO type III KNF which was significantly based on the multiple regression analysis tests. From histopathology a score of 9.2 was obtained which gave a strong positive result so it can be concluded that the correlation between the expression levels of $\mathrm{S} 100$ protein to the clinical stage of the KNF WHO type III was positively strong

These results are in accordance with Tsuji et al. research in 2006 regarding the effect of RAGE by LMP1 on metastatic GB patients with nasopharyngeal carcinoma. In this study, 42 paraffin blocks of NPC patients consisting of 3 patients without enlarged KGB and 33 patients with nodes enlargement (N1-3) were then analyzed and stained by immunohistochemistry. The result is RAGE expression $>20 \%$ in 29 subjects with $p=0.0093$ after Mann-Whitney test. In this study, it was concluded that there was a relationship between the expression of RAGE and metastatic nodes patients with NPC [11].

The study by Maletzki et al. In 2012 stated that the S100 protein was used as a diagnostic and prognostic factor in colorectal and hepatocellular malignancies where there was an increase in the expression of $\mathrm{S} 100$ protein from the prenacolic phase until metastasis occurred. This was concluded after finding 161 articles over a 10-year study of the expression of S100 
proteins in various malignancies related to poor differentiation, progression, advanced stage, and metastatic growth. Expression of S100 protein is considered a poor prognostic factor in some cancers [15].

\section{CONCLUSION}

There were significant correlation between S100 protein expression levels to clinical stage nasopharyngeal carcinoma WHO type III.

\section{REFERENCE}

[1] Wei W, Chua D. Nasopharyngal cancer. Dalam Bailey BJ, Healey GB, Johnson JT, Rosen CA dkk, penyunting. Head and neck surgeryotolaryngology Philadelphia Lippincott Williams \& Wilkins Edisi ke-4. 1875;97.

[2] Wildeman MAM. Current problems and possible solutions in the treatment of nasopharyngeal carcinoma in Indonesia: Universiteit van Amsterdam [Host]; 2013.

[3] Cahyadi I, Dewi YA. Status Pendengaran pada Penderita Karsinoma Nasofaring.

[4] Yahwardiah S, Munir D. Hubungan anti bodi anti Epstein-Barr-Virus (EBNA-1) Dengan Karsinoma Nasofaring Pada Pasien Etnis Batak Di Medan.

[5] Sabirin MSM, Permana AD, Soeseno B. Epidemiologi Penderita Tumor Ganas Kepala Leher di Departemen Telinga Hidung Tenggorokan-Kepala Leher Rumah Sakit Dr. Hasan Sadikin Bandung, Indonesia, Periode 2010-2014. Tunas Medika Jurnal Kedokteran \& Kesehatan. 2016;3(1).

[6] Adham M, Kurniawan AN, Muhtadi AI, Roezin A, Hermani B, Gondhowiardjo S, et al. Nasopharyngeal carcinoma in Indonesia: epidemiology, incidence, signs, and symptoms at presentation. Chinese journal of cancer. 2012;31(4):185.

[7] Lauriola L, Michetti F, Sentinelli S, Cocchia D. Detection of S-100 labelled cells in nasopharyngeal carcinoma. Journal of clinical pathology. 1984;37(11):1235-8.

[8] Nomori H, Watanabe S, Nakajima T, Shimosato Y, Kameya T. Histiocytes in nasopharyngeal carcinoma in relation to prognosis. Cancer. 1986;57(1):100-5.

[9] Hung SH, Chen PY, Lin HC, Ting J, Chung SD. Association of rhinosinusitis with nasopharyngeal carcinoma: A population - based study. The Laryngoscope. 2014;124(7):1515-20.

[10] Tulalamba W, Janvilisri T. Nasopharyngeal carcinoma signaling pathway: an update on molecular biomarkers. International journal of cell biology. 2012;2012.

[11] Tsuji A, Wakisaka N, Kondo S, Murono S, Furukawa M, Yoshizaki T. Induction of receptor for advanced glycation end products by EBV latent membrane protein 1 and its correlation with angiogenesis and cervical lymph node metastasis in nasopharyngeal carcinoma. Clinical Cancer Research. 2008;14(17):5368-75.

[12] Sinha P, Okoro C, Foell D, Freeze HH, Ostrand-Rosenberg S, Srikrishna G. Proinflammatory S100 proteins regulate the accumulation of myeloid-derived suppressor cells. The Journal of Immunology. 2008;181(7):4666-75.

[13] Karin M, Greten FR. NF-кB: linking inflammation and immunity to cancer development and progression. Nature reviews immunology. 2005;5(10):749-59.

[14] Colotta F, Allavena P, Sica A, Garlanda C, Mantovani A. Cancerrelated inflammation, the seventh hallmark of cancer: links to genetic instability. Carcinogenesis. 2009;30(7):1073-81.

[15] Zheng H, Li L, Hu D, Deng X, Cao Y. Role of Epstein-Barr virus encoded latent membrane protein 1 in the carcinogenesis of nasopharyngeal carcinoma. Cell Mol Immunol. 2007;4(3):185-96. 